Journal of Applied Biology \& Biotechnology Vol. 5 (01), pp. 018-020, Jan-Feb, 2017

Available online at http://www.jabonline.in

DOI: $10.7324 / \mathrm{JABB} .2017 .50103$

(c) $\mathrm{BY}-\mathrm{NC}-\mathrm{SA}$

\title{
Identification of heterozygous cases of Bovine leukocyte adhesion deficiency (BLAD) in Indian Holstein crossbred bulls
}

\author{
Rosaiah Kotikalapudi ${ }^{1}$, Rajesh Kumar Patel $^{2^{*}}$, Murali Kommuri ${ }^{1}$ \\ ${ }^{1}$ Sandor Life Sciences, ${ }^{2}$ Sandor Animal Biogenics, Hyderabad- 500034, Telangana, India.
}

\begin{tabular}{|c|c|}
\hline ARTICLE INFO & ABSTRACT \\
\hline $\begin{array}{l}\text { Article history: } \\
\text { Received on: } 04 / 10 / 2016 \\
\text { Revised on: } 09 / 11 / 2016 \\
\text { Accepted on: } 18 / 11 / 2016 \\
\text { Available online: } 20 / 01 / 2017\end{array}$ & $\begin{array}{l}\text { BLAD is an Autosomal genetic disorder mainly in Holstein Friesian (HF) and HF crossbreds are major concern } \\
\text { worldwide as heterozygous (carrier) looks normal and therefore, used for breeding programmes. During the last } \\
\text { one and half years, blood samples were collected in the heparinized blood collecting tubes from } 570 \text { dairy bulls } \\
\text { including } 11 \mathrm{HF} \text { and } 81 \mathrm{HF} \text { crossbred bulls for investigation of heterozygous/carrier animals for various genetic } \\
\text { disorders, including Bovine Leukocyte Adhesion Deficiency Syndrome. The DNA extraction, PCR and RFLP }\end{array}$ \\
\hline $\begin{array}{l}\text { Key words: } \\
\text { BLAD, CD18, Autosomal } \\
\text { recessive, PCR-RFLP, }\end{array}$ & $\begin{array}{l}\text { were performed to find out carrier animals. PCR-RFLP technique exhibited a polymorphism in CD18 gene in two } \\
\text { Holstein crossbred bulls, which were confirmed by sequencing. The percentage of recessive allele in Holstein and } \\
\text { Holstein crossbred samples was calculated to be } 2.17 \text {. Rest all animals were found normal. }\end{array}$ \\
\hline
\end{tabular}
Carrier.

\section{INTRODUCTION}

Genetic disorders, especially autosomal recessive, are major concern worldwide as the carriers or heterozygous in cattle population look normal and therefore, often used for breeding through artificial insemination (AI) based on their genetic merits. Holstein Friesian (HF), a breed that dominates the global dairy industry, is high yielding animals in the world therefore being used for crossbreeding programmes in India. Extensive use of HF bulls and unaware of their breed specific genetic disorders in the past, autosomal recessive genetic disorders have been widely spread in $\mathrm{HF}$ and HF crossbred cattle in India. Many HF and HF crossbreds especially bulls have been identified as heterozygous or carriers for Bovine Leukocyte Adhesion Deficiency (BLAD) syndrome owing to an extensive and regular screening of bulls for genetic disorders at the research institutions, universities and diagnostic laboratories all over India. It is an autosomal recessive genetic disease [1] that affects especially Holstein Friesian breed. The defect was first identified in North American HF and was exported to other countries and therefore, the heterozygous and homozygous for BLAD have been identified worldwide [2]. Animal with BLAD is characterized by recurrent pneumonia, ulcerative and granulomatous stomatitis, enteritis with bacterial

* Corresponding Author

E-mail: rk_patel@sandor.co.in overgrowth, periodontitis, loss of teeth, delayed wound healing, persistent neutrophilia and death at an early age [3]. BLAD is a disease characterized by a reduced expression of the adhesion molecules on neutrophils, called $\beta$-integrins (a complex of the CD11/CD18 family of proteins that are structurally and functionally related to glycoproteins). The molecular basis of BLAD is a single point, which replaces adenine to guanine at 383 position of the CD18 gene that changes the amino acid, aspartic acid to glycine at amino acid 128 position in the functional protein. The mutation ultimately leads to wrong protein (CD18) that is impaired in function [1].

The gene is located on chromosome number 1 (BTA1). In India, where HF bulls are extensively used for pure and crossbreeding programmes, it is obvious to detect BLAD carriers in $\mathrm{HF}$ and HF crossbreds. BLAD carriers were first detected in India by Muralidharan et al. [4], in two young HF bulls which were born through artificial insemination with the imported semen.

After that the routine screening of BLAD in selected HF and HF crossbreds became mandatory. Later, BLAD carriers were regularly detected $[5,6,7,8,9,10]$. The regular occurrence of BLAD carriers in Holstein and Holstein crossbreds emphasize to continue the genetic testing for BLAD. Present article describes two more cases of BLAD heterozygous in Holstein crossbred bulls which were detected in routine screening during the last one and half years. 


\section{MATERIALS AND METHODS}

Blood samples were collected into the heparinized blood collecting tubes from $11 \mathrm{HF}$ and $81 \mathrm{HF}$ crossbred bulls out of 570 dairy bulls including various zebu and exotic cattle and buffalo breeds, during the last one and a half years (April 2015- September 2016) as mentioned in the table below.

\begin{tabular}{llc}
\hline & Cattle breed & No of animals genotyped for BLAD \\
\hline 1 & Holstein Friesian (HF) & 011 \\
2 & Holstein crossbred & 081 \\
3 & Jersey & 050 \\
4 & Jersey crossbred & 138 \\
5 & Tharparkar & 003 \\
6 & Rathi & 002 \\
7. & Ongole & 019 \\
8. & Panganur & 002 \\
9. & Gaolao & 007 \\
10. & Khillar & 009 \\
11 & Red Sindhi & 021 \\
12 & Sahiwal & 015 \\
13 & Hariana & 015 \\
14 & Gir & 001 \\
15 & Vachur & 007 \\
Sub-total & & 381 \\
Buffalo breeds & \\
15 & Murrah & 179 \\
16 & Nagpuri & 001 \\
17 & Pandarpuri & 009 \\
Total & & 570 \\
\hline
\end{tabular}

The DNA was extracted by the standard phenolchloroform method. The quality and quantity of DNA were determined using agarose gel electrophoresis and UV Spectrophotometry. As described by Kriegesmann et al. [11], 343 bp DNA fragment was amplified by Polymerase chain reaction (PCR), which was set by adding forward primer (5'CCTGCATCATATCCACCAG-3') and reverse primer (5'GTTTCAGGGGAAGATGGAG -3'). The PCR mix contained $1 X$ PCR buffer, $1.5 \mathrm{mM} \mathrm{MgCl}_{2}, 10 \mathrm{mM}$ dNTPs, $5 \mathrm{pM}$ each of forward and reverse primer, 5 Unit Taq DNA Polymerase, 50ng genomic DNA and distilled water to make a final volume of $18 \mu \mathrm{l}$. The PCR reaction included the following steps: predenaturation for 3 minutes at $94^{\circ} \mathrm{C}$ followed by 35 cycles of 30 seconds at $94^{\circ} \mathrm{C}$, 30 seconds at $61^{\circ} \mathrm{C}, 30$ seconds at $72^{\circ} \mathrm{C}$ and final extension for 10 minutes at $72^{\circ} \mathrm{C}$ for utilization of extra dNTPs in mixture. The amplified PCR product was digested by using $\operatorname{Taq} \mathrm{I}$ at $65^{\circ} \mathrm{C}$ for overnight. The digested product was visualized on $3 \%$ agarose gel. In order to confirm the polymorphism, the PCR product was sequenced along with the DNA of normal Holstein as a control. As described [12], a simple method to treat PCR products prior to sequencing using ExoSAP-IT was performed. After purification step of PCR product, it was sequenced by Applied Bio systems 3130XL Automated Sequencer using the ABI Big Dye Ver 3.1. Sequence analysis comparison was performed using the Codon Code Aligner 4.0.4 Software.

\section{RESULS AND DISCUSSION}

In our investigation, out of 570 bulls, two HF crossbred bulls were found to be heterozygous of BLAD (carriers) however; all other bulls were found normal as shown in figure- 1 and 2 for sample No. 1 and 2 respectively.

\section{Sample-1}
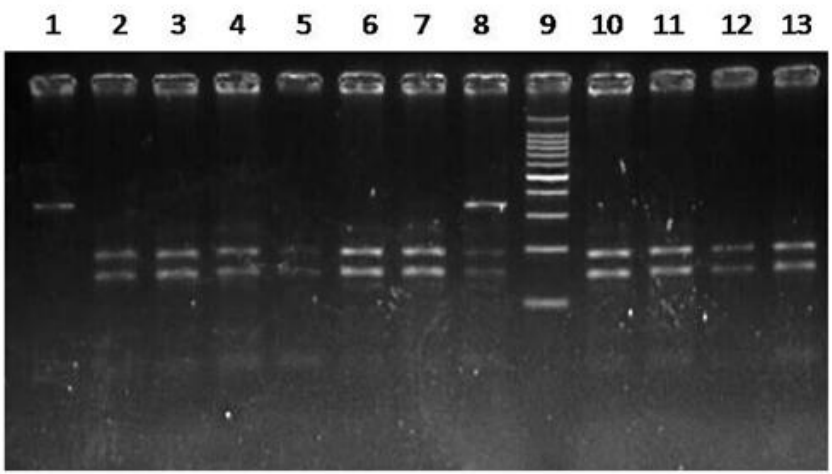

Fig. 1: Electrophoretogram (3\% agarose gel) of taql digested PCR product generated by amplification of genomic DNA using BLAD specific primers. Lane\# 1 is PCR product of 343bp size lane \# 2, 3, 4, 5, 6, 7, 10, 11, 12 \& 13 are RFLP products of $191 \mathrm{bp}$ and $152 \mathrm{bp}$, of normal animals, lane \# 8 are RFLP products of 343bp, 191bp \& 152bp of heterozygous/carrier animal and land \# 9 is gene ruler 100pb DNA ladder (Thermo scientific).

\section{Sample-2}

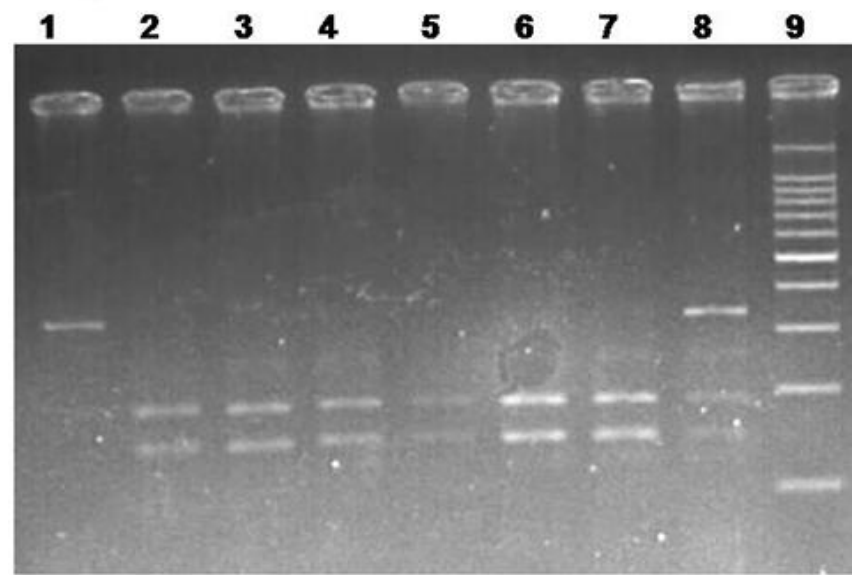

Fig. 2: Electrophoretogram (3\% agarose gel) of Taql digested PCR product generated by amplification of genomic DNA using BLAD specific primers. Lane \# 1 is PCR product of $343 \mathrm{bp}$ size, lane \# 2, 3, 4, 5, 6 \& 7 are RFLP products of $191 \mathrm{bp}$ and $152 \mathrm{bp}$ of normal animals, lane \# 8 are RFLP products of $343 \mathrm{bp}, 191 \mathrm{bp} \& 152 \mathrm{bp}$ of heterozygous/carrier animal and lane \# 9 is gene ruler 100pb DNA ladder (Thermo Scientific)

The percentage of the recessive allele in Holstein and Holstein crossbred bulls was calculated to be 2.17 . The size of the PCR product was $343 \mathrm{bp}$ and it was subjected to RFLP analysis using a Taq-1 restriction enzyme. In normal bulls, the PCR products yielded two fragments of $191 \mathrm{bp}$ and $152 \mathrm{bp}$, whereas in carrier (heterozygous) three fragments of $343 \mathrm{bp}, 191 \mathrm{bp}$ and $152 \mathrm{bp}$. PCR-RFLP technique was supported by sequencing to identify mutations in CD18 gene of both the samples (fig-3).

The arrows in the electropherogram (fig-3) are showing the mutation $(\mathrm{G}>\mathrm{A})$ at c.559 position in both the samples that is from $\mathrm{G}$ to $\mathrm{A}$ in one of the genes (heterozygous). Though the occurrence of BLAD carrier is quite rare, but cases of BLAD have been regularly detected in India. 


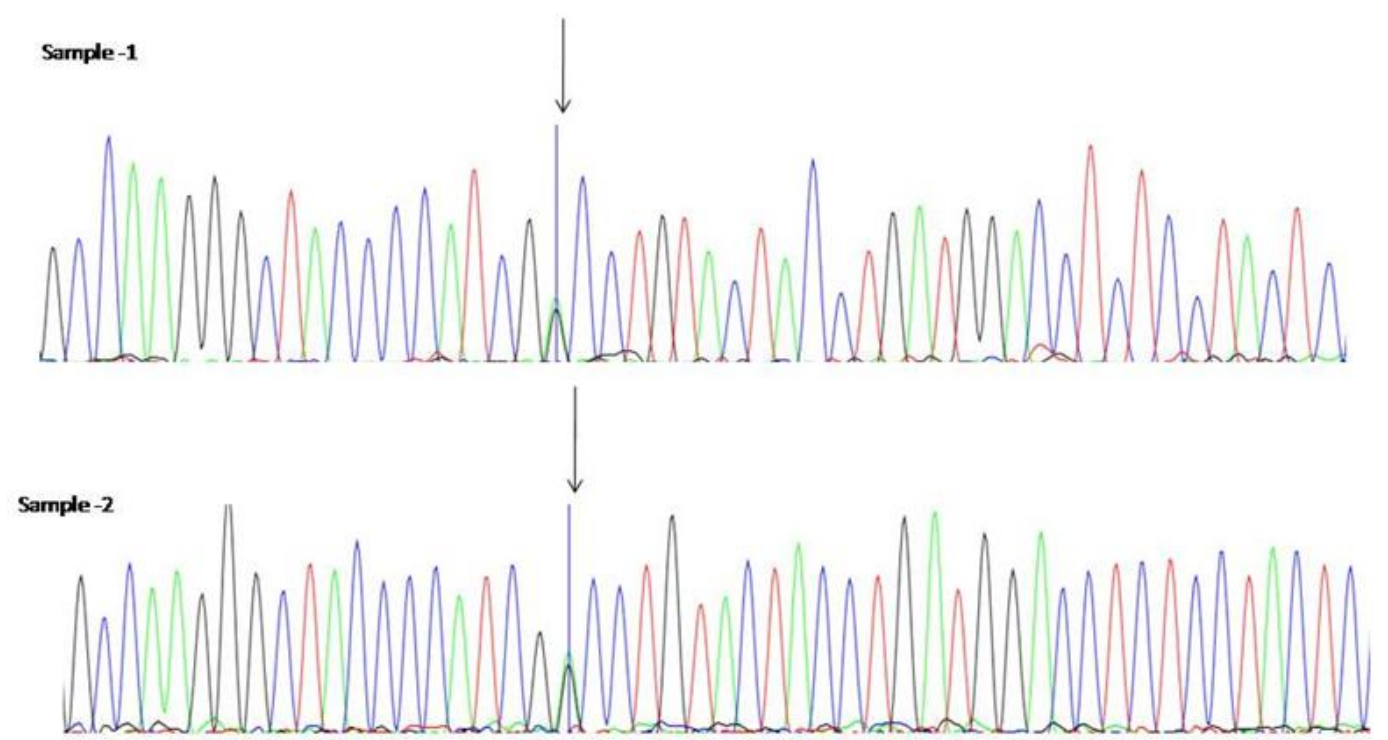

Fig. 3: Electropherogram of sample-1 \& 2. Arrows indicating heterozygous (G>A) mutation at c. 559 position of exon 5 CD 18 gene.

The percentage of BLAD carriers were earlier estimated ranging 1.0 to $4.76[4,5,6,8,9,10]$ during regular screening of the breeding bulls. As reported earlier [5], no cattle and buffalo breeds were found heterozygous for BLAD other than HF crossbreds in a present investigation. However, Factor XI deficiency, one of the autosomal genetic disorders was first time reported in zebu cattle, Sahiwal breed [13] indicating the possible occurrence of the genetic disorders in the Zebu cattle. The bulls found carrier/heterozygous for BLAD in the present investigation, were advised to be culled from bull rearing centre to avoid further propagation of the defective gene.

\section{Financial support and sponsorship: Nil.}

Conflict of Interests: There are no conflicts of interest.

\section{REFERENCES}

1. Shuster DE, Kehrli ME, Ackermann Jr. MR, Gilbert RO. Identification and prevalence of a genetic defect that causes leukocyte adhesion deficiency in Holstein cattle. Proc. Natl. Acad. Sci. USA. 1992; 89: 9225-9229.

2. Patel RK, Patel AK. Comparative review of recessive genetic disorders occurrence in Indian Cattle. Current Trend in Biotechnology and Pharmacy. 2014; 8 (3): 321-335.

3. Nagahata H, Noda H, Takahashi K, Kurosawa T, Sonoda M. Bovine granulocytopathy syndrome: Neutrophil dysfunction in Holstein Friesian calves. J. Vet. Med. Ser A. 1987; 34: $445-451$.

4. Muraleedharan P, Khoda VK, Grupe S, Mukhopadhya PN, Manfred $\mathrm{S}$, Mehta $\mathrm{HH}$. Incidence of hereditary citrullinaemia and bovine leukocyte adhesion deficiency syndrome in Indain dairy cattle (Bos Taurus, Bos indicus) and buffalo (Bubalus bubalis) population. Arch. Tierz. Dummerstorf. 1999; 42(4): 347-352.

5. Patel RK, Singh KM, Soni KJ, Chauhan JB, Sambasiva Rao KSR. Low incidence of Bovine Leukocyte Adhesion Deficiency (BLAD) carriers in Indian dairy cattle and buffalo breeds. Journal of Applied Genetics. 2007; 48(2): 153-155.
6. Yathish HM, Sharma A, Kumar V, Jain A, Chakraborty D, Singh A, Tantia MS, Joshi BK. Genetic polymorphism of CD18 gene in Karan Fries young bull calves using PCR-RFLP analysis. Curren Trend Biot Pharma, 2010; 4 (4): 900-907.

7. Mahdipour M, Sharma A, Dubey PP, Singh A, Tantia MS, Mishra B, Kumar V, Joshi BK. PCR based identification of bovine leukocyte adhesion deficiency syndrome (BLAD) carriers in Karan Fries bulls. Ind J Anim Sci, 2010; 80: 433-435.

8. Patel M, Patel RK, Singh KM, Rank DN, Thakur MC, Khan A. Detection of genetic polymorphism in CD18 gene in cattle by PCRRFLP. Wayamba J of Anim. Sci. 2011; Article No. 1305108850.

9. Roy A, Kotikalapudi R, Patel RK, Anantaneni R, Katragadda S. New cases of Bovine Leukocyte Adhesion Deficiency (BLAD) carriers in Indian Holstein cattle. International J Vet. Sci. 2012; 1(2): 80-82.

10. Patel RK, Kotikalapudi R, Sunkara PSS. Detection of new silent mutation at $348 \mathrm{bp}$ position in a CD18 gene in Holstein cattle normal and heterozygous for Bovine Leukocyte Adhesion Deficiency syndrome. Iranian J of Applied Anim. Sci. 2015; 5(1): 47-50.

11. Kriegesmann B, Jansen S, Baumgartner BG, Brenig B. Partial genomic structure of the bovine $\mathrm{CD} 18$ gene and the refinement of test for bovine leukocyte adhesion deficiency. J Dairy Sci, 1997; 80: 2547-2549.

12. Bell JR. A simple way to treat PCR products prior to sequencing using ExoSAP-IT. Bio. Techniques. 2008; 44: 834-834.

13. Mondal K, Chakravarti S, Ghosh AK, Kumar S, Nayak B, Nandi S, Sarkar U, Deb R, De A and Biswas J. Novel identification of Factor XI deficiency in Indian Sahiwal (Bos indicus) cattle. Mol Biol Rep. 2016; 43(4):213-219.

\section{How to cite this article:}

Kotikalapudi R, Patel R.K and Kommuri M, Identification of heterozygous cases of Bovine leukocyte adhesion deficiency (BLAD) in Indian Holstein crossbred bulls. J App Biol Biotech. 2017; 5 (01): 018-020. DOI: 10.7324/JABB.2017.50103 